\title{
SISTEM PENDUKUNG KEPUTUSAN PEMILIHAN PERGURUAN TINGGI SWASTA MENGGUNAKAN TOPSIS
}

\author{
Tati Mardiana; ${ }^{1}$ Siska Selvia Tanjung² \\ Program Studi Sistem Informasi \\ Universitas Bina Sarana Informatika \\ tati.mardiana@gmail.com; siskaselvia677@gmail.com
}

\begin{abstract}
Abstrak
Memilih perguruan tinggi yang tepat merupakan langkah penting bagi siswa dalam mempersiapkan karir dan masa depannya. Dengan pendidikan di perguruan tinggi, siswa meningkatkan kesempatannya untuk mendapatkan pekerjaan yang lebih baik. Tetapi keterbatasan daya tampung perguruan tinggi negeri membuat siswa dan orang tua harus memilih perguruan tinggi swasta yang sesuai dengan keinginan dan kemampuan. Kesalahan dalam memilih perguruan tinggi menyebabkan siswa mengalami kegagalan dalam menjalankan pendidikan di perguruan tinggi tersebut. Oleh karena itu, siswa dan orang tua perlu mempertimbangkan beberapa faktor seperti status akreditasi, biaya, jumlah mahasiswa, jumlah dosen, fasilitas, program studi dan lain-lain untuk memilih perguruan tinggi swasta. Kendati demikian, banyak siswa dan orang tua yang mengalami kebingungan dalam memilih perguruan tinggi swasta. Hal ini disebabkan karena banyaknya perguruan tinggi swasta dan minimnya informasi tentang perguruan tinggi swasta tersebut. Tujuan penelitian ini adalah membangun sistem pendukung keputusan pemilihan perguruan tinggi swasta yang sesuai keinginan dan kemampuan siswa dan orang tua. Penelitian ini menggunakan logika Fuzzy Multiple Attribute Decision Making (FMADM) dengan metode Technique for Order Preference by Similarity to Ideal Solution (TOPSIS) untuk melakukan perangkingan dari setiap alternatif perguruan tinggi swasta. Hasil pengujian menunjukkan bahwa kinerja sistem memenuhi persyaratan fungsional dan kinerja sistem mencapai akurasi sebesar 83,33\%. Sistem pendukung keputusan ini membantu siswa dan orang tua membuat keputusan untuk memilih perguruan tinggi swasta yang sesuai dengan keinginan dan kemampuan mereka secara akurat.
\end{abstract}

Kata kunci: pemilihan, pendidikan, perguruan tinggi swasta, TOPSIS, sistem pendukung keputusan

\begin{abstract}
Choosing the right college is a crucial step for students in preparing for their careers and future. With education at the college, the student increases their chances of getting better jobs. But because of the limited capacity of public college, students and parents must select a private college that agrees with desires and abilities. Errors in choosing a college result in students experiencing failure in carrying out education in the college. Therefore, students and parents need to consider several factors such as accreditation status, costs, the number of students, lecturers, facilities, study programs, and others to select a private college. Nevertheless, students and parents experience confusion in choosing a private college. This is due to many private colleges and the lack of information about these private colleges. The aim of this study is to build a decision support system to select a private college that matches the desires and abilities of students and parents. This study uses Fuzzy Multiple Attribute Decision Making (FMADM) logic with the Technique for Order Preference by Similarity to Ideal Solution (TOPSIS) method to rank each alternative private college. The test results showed that the features of the supporting system are functioning properly and the system performance reaches an accuracy of $83.33 \%$. This decision support system helps students and parents make decisions to select a private college that according to their desires and abilities accurately.
\end{abstract}

Keywords: selection, education, private college, TOPSIS, decision support system

\section{PENDAHULUAN}

Kesadaran masyarakat Indonesia akan pentingnya melanjutkan pendidikan ke jenjang perguruan tinggi dalam beberapa tahun terakhir mengalami peningkatan yang cukup signifikan. Pada tahun 2017, angka partisipasi kasar (APK) perguruan tinggi menunjukkan persentase jumlah 
penduduk yang sedang kuliah di perguruan tinggi terhadap jumlah penduduk usia kuliah (19-23 tahun) sebesar 33,37\% lebih tinggi 7,61\% dibandingkan tahun 2014 (Badan Pusat Statistik, 2018). jumlah lulusan Sekolah Menengah ke Atas (SMA) dan Sekolah Menengah Kejuruan (SMK) pada tahun 2017 sebesar 2,707,954 (Kementerian Pendidikan dan Kebudayaan, 2017). Dari angka tersebut, dengan APK perguruan tinggi sebesar 33,37\% maka diperkirakan lulusan SMA dan SMK yang melanjutkan ke perguruan tinggi sekitar 90,364,425 orang.

Berdasarkan data dari Pangkalan Data Pendidikan Tinggi (PDPT) pada tahun 2017 terdapat 122 Perguruan Tinggi Negeri (PTN) dan 3154 Perguruan Tinggi Swasta (PTS) dengan komposisi berdasarkan berbagai bentuk pendidikan yang terdiri atas akademi, politeknik, sekolah tinggi, universitas, institut dan akademi komunitas (Kemeristekdikti, 2017). Setiap tahun daya tampung PTN sebesar 250.000 sehingga sekitar 90,114,425 lulusan SMA dan SMK akan melanjutkan kuliah di perguruan tinggi swasta.

Setiap orang tua menginginkan pendidikan yang terbaik untuk putra-putrinya. Memilih perguruan tinggi swasta yang tepat sangat penting bagi calon mahasiswa untuk mempersiapkan karir dan masa depannya. Namun, banyak orang tua dan calon mahasiswa yang mengalami kebingungan dalam memilih perguruan tinggi swasta karena banyaknya pilihan dan minimnya informasi tentang perguruan tinggi swasta tersebut. Kesalahan dalam memilih perguruan tinggi menyebabkan calon mahasiswa mengalami kegagalan dalam menjalankan pendidikan di perguruan tinggi tersebut (Surya, 2017).

Pengambilan keputusan yang cepat dan baik membutuhkan sebuah sistem pendukung keputusan yang akan memberikan informasi sebagai dasar pengambilan keputusan berdasarkan data-data mengenai setiap alternatif yang diolah dengan suatu mekanisme tertentu untuk selanjutnya menjadi dasar pengambilan keputusan. Proses pengambilan keputusan yang memiliki beberapa kriteria menggunakan logika Fuzzy Multiple Attribute Decision Making (FMADM) untuk mencari alternatif optimal dari sejumlah alternatif dengan kriteria tertentu (Mardiana, 2018). Metode yang dapat digunakan untuk menyelesaikan permasalahan menggunakan logika FMADM adalah Simple Additive Weighted (SAW), Weighted Product (WP), ELECTRE, Technique for Order Preference by Similarity to Ideal Solution (TOPSIS), dan Analytic Hierarchy Process (AHP). Beberapa peneliti telah melakukan penelitian terkait permasalahan pemilihan jurusan perguruan tinggi.

(Budilaksono, Suwarno, \& Herwanto, 2016) mengusulkan model pengambilan keputusan untuk pemilihan perguruan tinggi swasta program studi teknik informatika strata satu dengan metode AHP dan Preference Ranking Organization Method for Enrichment Evaluation (Promethee). Proses pengambilan keputusan menggunakan 7 kriteria, 26 sub kriteria dan 4 alternatif. Sedangkan (Triono \& Aminudin, 2017) mengusulkan model pengambilan keputusan untuk pemilihan perguruan tinggi menggunakan metode SAW. Metode SAW mampu memberikan rekomendasi perguruan tinggi berdasarkan bobot kriteria penilaian yang telah ditentukan kepada calon mahasiswa dan orang tua. Penelitian berikutnya (Danang \& Nisar, 2017) mengusulkan sistem pendukung keputusan pemilihan perguruan tinggi jurusan komputer di Semarang dengan metode AHP berdasarkan delapan kriteria, yaitu akreditasi institusi, jurusan, akreditasi jurusan, staf pengajar, peminat, biaya, prospek kerja, fasilitas, dan waktu kuliah. Selain itu, Selain itu (Walidain \& Ardian, 2017) juga mengusulkan sistem pendukung keputusan pemilihan perguruan tinggi dan jurusan menggunakan TOPSIS untuk menghasilkan ranking perguruan tinggi dan jurusan sehingga diharapkan dalam pemilihan perguruan tinggi dan jurusan yang direkomendasikan benar-benar sesuai dengan keinginan, dan kemampuan siswa.

Berdasarkan penelitian sebelumnya maka tujuan penelitian adalah menghasilkan sistem pendukung keputusan memilih perguruan tinggi swasta menggunakan TOPSIS untuk memberikan rekomendasi perguruan tinggi yang perguruan tinggi swasta yang sesuai dengan keinginan dan kemampuan siswa dan orang tua.

\section{METODE PENELITIAN}

\section{Disain Penelitian}

Sesuai dengan permasalahan yang telah dikemukakan sebelumnya, maka jenis penelitian ini adalah penelitian eksperimen. Objek penelitian ini Penelitian dilakukan pada bulan Maret sampai dengan bulan September 2017 di Jakarta. Penelitian ini berawal dari pengamatan tentang pemiihan perguruan tinggi swasta. Berdasarkan hasil pengamatan, calon siswa dan orang tua mengalami kesulitan dalam menentukan perguruan tinggi yang sesuai keinginan dan kemampuannya.. Solusi dari permasalahan ini adalah menerapkan TOPSIS dalam sistem pendukung keputusan untuk memilih perguruan 
tinggi swasta. Sistem pendukung keputusan ini berbasis web yang dapat diakses oleh calon siswa dan orang tua kapan saja dan dimana saja untuk memperoleh informasi dan rekomendasi perguruan tinggi yang sesuai keinginan dan kemampuan secara cepat dan akurat. Berdasarkan uraian di atas, kerangka penelitian pada tugas

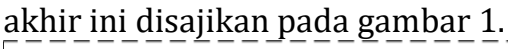

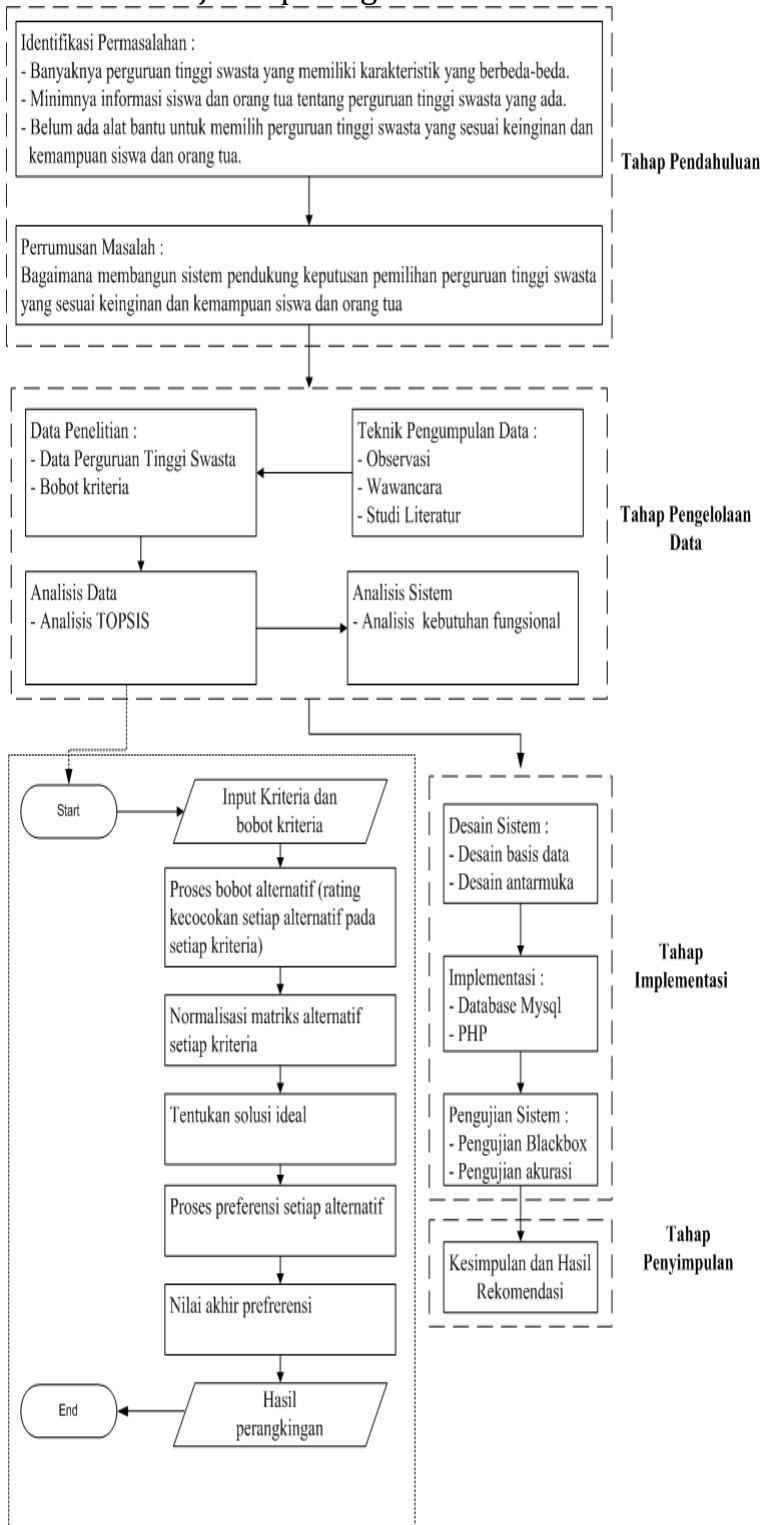

Sumber : (Mardiana \& Tanjung, 2017)

Gambar 1. Kerangka Pemikiran

Data, Instrumen, dan Teknik Pengumpulan Data

Penelitian ini mengunakan data primer dan skunder. Data Primer diperoleh secara langsung dari sumber, misalnya data-data hasil wawancara dan diskusi langsung dengan orang tua dan siswa SMA/SMK Kelas IX. Sedangkan data sekunder berupa data perguruan tinggi swasta di
Indonesia yang diperoleh dari situs Pangkalan Data Pendidikan Tinggi, literatur-literatur, jurnaljurnal penelitian, maupun data dokumen yang diperlukan untuk menyusun penelitian ini.

Instrumen penelitian merupakan alat bantu bagi peneliti untuk mengumpulkan data sehingga kegiatan tersebut menjadi sistematis dan efisien. Instrumen yang digunakan pada penelitian ini adalah pedoman wawancara dan panduan studi dokumentasi.

Teknik pengumpulan data yang dilakukan dalam tugas akhir ini, sebagai berikut:

a. Observasi

Observasi dilakukan dengan mengumpulkan data dengan melakukan pengamatan secara langung terhadap proses pendaftaran pada perguruan tinggi swasta di Jakarta.

b. Wawancara

Wawancara dilakukan kepada pelaku usaha waralaba makanan untuk memperoleh informasi lebih mendalam terkait proses pemilihan perguruan tinggi swasta yang tepat dan sesuai keinginan.

c. Studi Pustaka

Studi pustaka dilakukan dengan mengumpulkan dan mempelajari literatur yang berkaitan dengan pemecahan masalah pemilihan perguruan tinggi swasta. Sumber literatur berupa buku teks, karya ilmiah, dan situs-situs penunjang. Kegunaan metode ini diharapkan dapat mempertegas teori serta keperluan analisis dan mendapatkan data yang sesungguhnya.

\section{Teknik Analisis Data}

Berdasarkan data yang sudah terkumpul, dilakukan analisis mengenai kriteria dan bagaimana penerapan metode TOPSIS dalam studi kasus pemilihan perguruan tinggi swasta. Kriteriakriteria dalam pemilihan perguruan tinggi swasta didapatkan dari Pangkalan Data Perguruan Tinggi (PDPT). Ada enam kriteria dalam pemilihan perguruan tinggi swasta, antara lain akreditasi (A), jumlah mahasiswa(M), jumlah dosen (D), biaya (B), jumlah fasilitas (F) dan jumlah jurusan (J). Contoh kasus yang digunakan dalam analisis proses pengambilan keputusan sebanyak tiga perguruan tinggi swasta yang disusun pada tabel 1 dan bobot dari masing-masing kriteria seperti terlihat pada tabel 2 .

Tabel 1. Alternatif perguruan tinggi swasta

\begin{tabular}{ccccccc}
\hline Alternatif & A & M & D & B & F & J \\
\hline UNAS & B & 6,495 & 313 & 4.6 & 7 & 32 \\
\hline BINUS & B & 28,437 & 1,001 & 14.7 & 11 & 34 \\
\hline Trisakti & B & 23,149 & 895 & 7.3 & 27 & 47 \\
\hline
\end{tabular}

Sumber : (Mardiana \& Tanjung, 2017) 
Tabel 2. Bobot Kriteria Perguruan Tinggi Swasta

\begin{tabular}{clc}
\hline Kriteria & \multicolumn{1}{c}{ Keterangan } & Bobot \\
\hline C1 & Akreditasi & 5 \\
\hline C2 & Jumlah mahasiswa & 2 \\
\hline C3 & Jumlah dosen & 4 \\
\hline C4 & Biaya & 5 \\
\hline C5 & Fasilitas & 5 \\
\hline C6 & Jumlah jurusan & 3 \\
\hline
\end{tabular}

Sumber : (Mardiana \& Tanjung, 2017)

Untuk memperoleh ranking kecocokan dari alternatif pemilihan perguruan tinggi swasta maka harus menentukan nilai kecocokan antara alternatif dan kriteria dengan interval dari 1 sampai 5, dengan ketentuan 1 = Tidak Baik; 2 = Kurang Baik; 3 = Cukup Baik; 4 = Baik; 5 = Sangat baik. Nilai kecocokan pada setiap kriteria dapat dilihat pada tabel 3 dan hasil rangking kecocokan dari setiap alternatif pada setiap kriterianya dapat dilihat pada tabel 4 .

Tabel 3. Nilai Kecocokan Pada Setiap Kriteria

\begin{tabular}{|c|c|c|c|}
\hline No & Atribut & Nilai & $\begin{array}{c}\text { Nilai } \\
\text { Kecocokan }\end{array}$ \\
\hline \multirow[t]{4}{*}{$\mathrm{C} 1$} & Akreditasi & $\begin{array}{l}\text { Tidak } \\
\text { terakreditasi }\end{array}$ & 2 \\
\hline & & $\mathrm{C}$ & 3 \\
\hline & & $\mathrm{B}$ & 4 \\
\hline & & $\mathrm{A}$ & 5 \\
\hline \multirow[t]{5}{*}{$\mathrm{C} 2$} & Jumlah & $<1000$ & 1 \\
\hline & Mahasiswa & $1000-7000$ & 2 \\
\hline & & $7001-14.000$ & 3 \\
\hline & & $14.001-30.000$ & 4 \\
\hline & & $>30.000$ & 5 \\
\hline \multirow[t]{5}{*}{$\mathrm{C} 3$} & Jumlah & $<100$ & 1 \\
\hline & Dosen & $101-300$ & 2 \\
\hline & & $301-700$ & 3 \\
\hline & & $701-1000$ & 4 \\
\hline & & $>1000$ & 5 \\
\hline \multirow[t]{5}{*}{$\mathrm{C} 4$} & Biaya & $>20 \mathrm{jt}$ & 1 \\
\hline & & $16 \mathrm{jt}-20 \mathrm{jt}$ & 2 \\
\hline & & $11 \mathrm{jt}-15 \mathrm{jt}$ & 3 \\
\hline & & $6 \mathrm{jt}-10 \mathrm{jt}$ & 4 \\
\hline & & $1 \mathrm{jt}-5 \mathrm{jt}$ & 5 \\
\hline \multirow[t]{5}{*}{ C5 } & Fasilitas & $<5$ & 1 \\
\hline & & $5-8$ & 2 \\
\hline & & $9-12$ & 3 \\
\hline & & $13-16$ & 4 \\
\hline & & $>16$ & 5 \\
\hline \multirow[t]{5}{*}{ C6 } & Jumlah & $<15$ & 1 \\
\hline & Jurusan & $15-30$ & 2 \\
\hline & & $31-45$ & 3 \\
\hline & & $46-60$ & 4 \\
\hline & & $>60$ & 5 \\
\hline
\end{tabular}

Sumber : (Mardiana \& Tanjung, 2017)
Tabel 4. Nilai Rangking Kecocokan Alternatif Pada Setiap Kriteria

\begin{tabular}{ccccccc}
\hline Alternatif & C1 & C2 & C3 & C4 & C5 & C6 \\
\hline UNAS & 4 & 2 & 3 & 5 & 2 & 3 \\
\hline BINUS & 4 & 4 & 5 & 3 & 3 & 3 \\
\hline Trisakti & 4 & 4 & 4 & 4 & 5 & 4
\end{tabular}

Sumber : (Mardiana \& Tanjung, 2017)

Langkah-langkah yang dilakukan dalam menyelesaikan suatu permasalahan menggunakan TOPSIS sebagai berikut :

1. Menggambarkan alternatif (m) dan kriteria

(n) ke dalam sebuah matriks, dimana Xij adalah pengukuran pilihan dari alternatif $\mathrm{k}$ e-i dan kriteria ke-j. Matriks ini dapat dilihat pada persamaan satu.

$D=\begin{array}{lll}X_{11} & X_{12} & X_{13} \\ X_{21} & X_{22} & X_{23} \\ X_{i 1} & X_{i 1} & X_{i 1}\end{array}$

Hasil matriks Xij sebagai berikut :

$D=\begin{array}{llllll}4 & 2 & 3 & 5 & 2 & 3 \\ 4 & 4 & 5 & 3 & 3 & 3 \\ 4 & 4 & 4 & 4 & 5 & 4\end{array}$

2. Membuat matriks $R$ yaitu matriks keputusan ternormalisasi

Setiap normalisasi dari nilai rij dapat dilakukan dengan perhitungan menggunakan persamaan dua. $r i j=\frac{X_{i j}}{\sqrt{\sum_{i=1}^{m} X_{i j}^{2}}}$

Hasil matriks ternormalisasi R sebagai berikut $\mathrm{R}$
$\left[\begin{array}{llllll}0,5774 & 0,3333 & 0,4243 & 0,7071 & 0,3244 & 0,5145 \\ 0,5774 & 0,6667 & 0,7071 & 0,4242 & 0,4667 & 0,5145 \\ 0,5774 & 0,6667 & 0,5657 & 0,5657 & 0,8111 & 0,6860\end{array}\right]$

3. Membuat pembobotan pada matriks yang telah dinormalisasi Setelah dinormalisasi, setiap kolom pada matriks $\mathrm{R}$ dikalikan dengan bobot (wj) untuk menghasilkan matriks pada persamaan tiga.

$$
D=\begin{array}{ccc}
W_{1} r_{11} & W_{1} r_{12} & W_{n} r_{n} \\
W_{2} r_{21} & \ldots \ldots & \ldots \ldots \\
W_{j} r_{m 1} & W_{j} r_{m 2} & W_{1} r_{m m}
\end{array}
$$

Hasil perkalian matriks $\mathrm{W} * \mathrm{R}$ sebagai berikut :

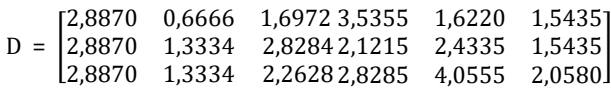

4. Menentukan nilai solusi ideal positif dan solusi ideal negatif. Solusi ideal dinotasikan A+, sedangkan solusi ideal negatif dinotasikan 
A-. Persamaan untuk menentukan solusi ideal dapat dilihat pada persamaan empat.

$$
\begin{aligned}
A+= & \left\{\left(\max V_{i j} \mid j € j^{\prime}\right),\right. \\
& =1,2,3, \ldots, m\}=V 1+V 2+\ldots \ldots+V n\} \\
A-\quad & \left\{\left(\max V i j \mid j € j^{\prime}\right),\left(\min V i j \mid j € j^{\prime}\right),\right. \\
= & 1,2,3, \ldots, m\}=V 1-V 2-\ldots . .-V n\}
\end{aligned}
$$

(4)

$\mathrm{J}=\{\mathrm{j}=1,2,3, \ldots ., \mathrm{n}$ dan $\mathrm{j}$ merupakan benefit criteria\}

$\mathrm{J}^{\prime} \quad=\{\mathrm{j}=1,2,3, \ldots ., \mathrm{n}$ dan $\mathrm{j}$ merupakan benefit criteria\}

Hasil matrik solusi ideal positif $\left(\mathrm{A}^{+}\right)$dan matrik solusi ideal negatif (A.).

$A^{+}$
$=\left[\begin{array}{llllll}2,8870 & 1,3334 & 2,8284 & 3,5355 & 4,0555 & 2,0580\end{array}\right]$
$A^{-}$
$=\left[\begin{array}{llllll}2,8865 & 0,6666 & 1,6972 & 2,1215 & 1,6220 & 1,5435\end{array}\right]$

5. Menghitung separation measure. Separation measure ini merupakan pengukuran jarak dari suatu alternatif ke solusi ideal positif dan solusi ideal negatif. Perhitungan solusi ideal positif dapat dilihat pada persamaan lima :

$\mathrm{Si}^{+}=\sqrt{\sum_{i=1}^{n}\left(Y_{i}^{+}-Y_{i j}+\right)^{2}}$

Dengan $I=1,2,3, \ldots, n$

Perhitungan solusi ideal negatif dapat dilihat pada persamaan enam :

$\mathrm{Si}^{+}=\sqrt{\sum_{i=1}^{n}\left(V_{i j}-V_{j}-\right)^{2}}$

Dengan $I=1,2,3, \ldots, n$

Hasil pengukuran jarak dari suatu alternatif ke solusi ideal positif dan solusi ideal negatif sebagai berikut:

$\mathrm{S} 1+=2.8126$

$\mathrm{S} 2+=2,2125$

$\mathrm{S} 3+=0,9054$

$\mathrm{S} 1-=1,4140$

$\mathrm{S} 2-=1,5436$

S3- $=2,7297$

6. Menghitung nilai preferensi untuk setiap al ternatif. Untuk menentukan ranking tiap-tiap alternatif yang ada maka perlu dihitung terlebih dahulu nilai preferensi dari tiap alternatif. Perhitungan nilai preferensi dapat dilihat melalui persamaan tujuh.

$V_{i}^{+}=\frac{s_{i}^{-}}{S_{i}^{+}+S_{i}^{-}}$
Dimana $0<\mathrm{C}_{\mathrm{i}}^{+}<1$ dan $\mathrm{i}=1,2,3, \ldots, \mathrm{m}$

Setelah didapat nilai $\mathrm{Si}+$, maka alternatif dapat diranking berdasarkan urutan Si+. Dari hasil perankingan ini dapat dilihat alternatif terbaik yaitu alternatif yang memiliki jarak terpendek dari solusi ideal dan berjarak terjauh dari solusi ideal negatif. Nilai preferensi untuk setiap alternatif sebagai berikut :

$\mathrm{V} 1=0,3345$

$\mathrm{V} 2=0,4110$

V3 $=0,7509$

Dari perhitungan diatas dapat diperoleh nilai V3 memiliki nilai terbesar, sehingga rekomendasi perguruan tinggi swasta yang dipilih untuk melanjutkan pendidikan adalah Universitas Trisakti.

\section{HASIL PENELITIAN DAN PEMBAHASAN}

\section{Desain Sistem}

Setelah menentukan pemodelan yang akan digunakan dalam sistem pendukung keputusan, maka langkah selanjutnya adalah membuat desain Diagram Alur Data (DAD). Pemakai yang akan berinteraksi dengan Sistem Pendukung Keputusan ini adalah administrator dan pengguna (siswa atau orang tua).

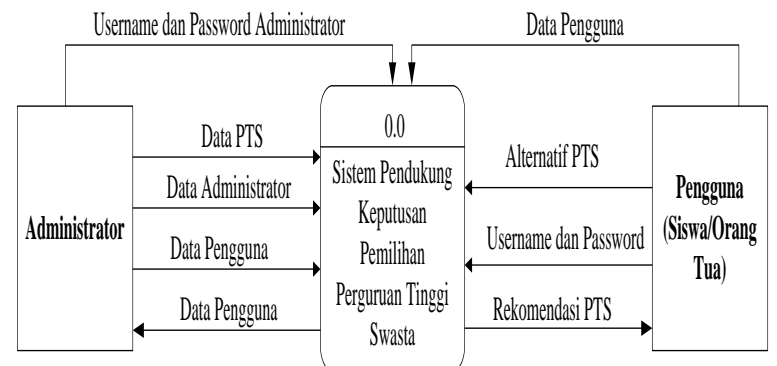

Sumber : (Mardiana \& Tanjung, 2017)

Gambar 2. Desain Diagram Konteks Sistem Pendukung Keputusan Pemilihan Perguruan Tingi Swasta 


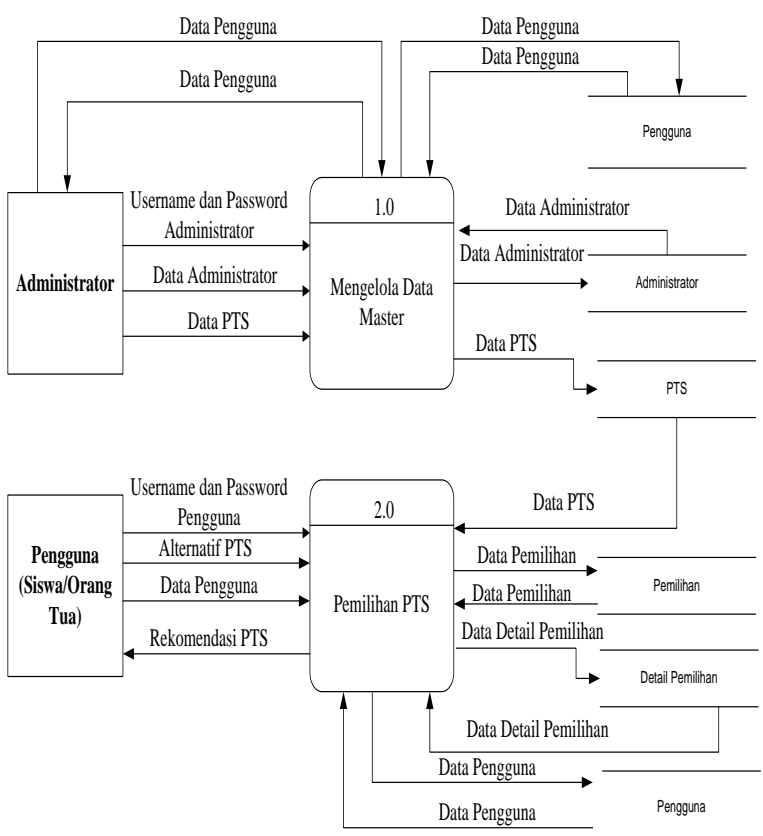

Sumber : (Mardiana \& Tanjung, 2017)

Gambar 3. Desain Diagram Nol Sistem Pendukung Keputusan Pemilihan Perguruan Tingi Swasta

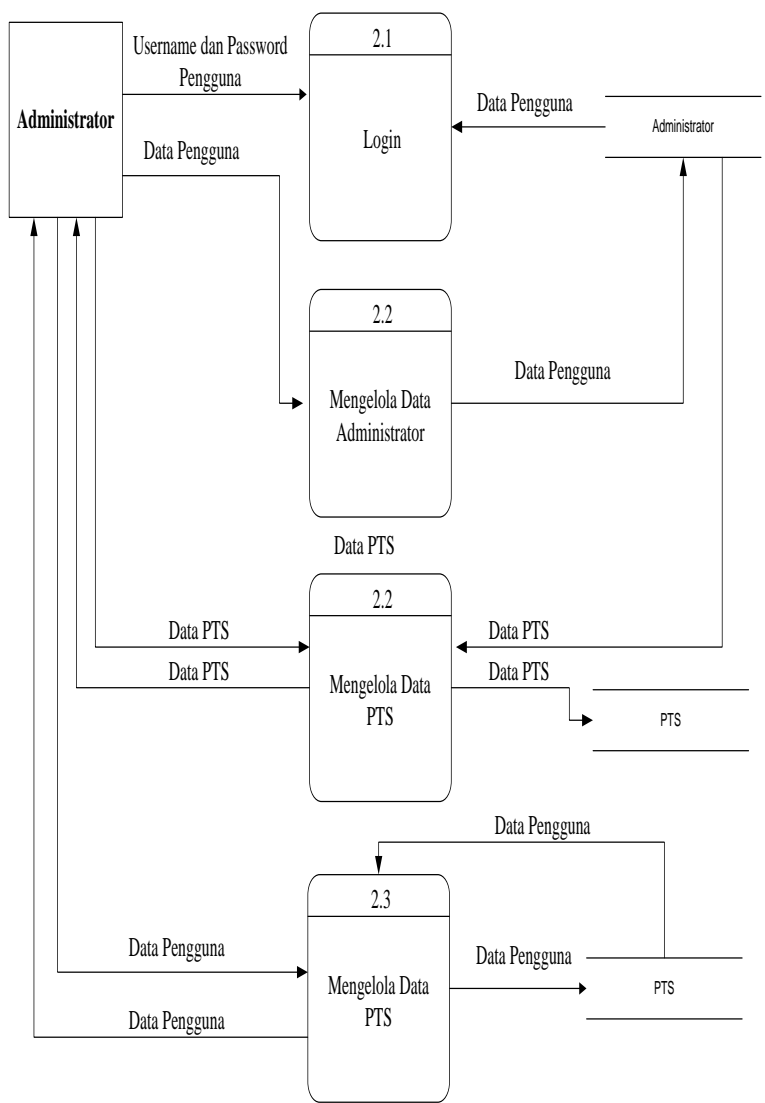

Sumber : (Mardiana \& Tanjung, 2017)

Gambar 4. Desain Diagram Detail 1.0 Sistem

Pendukung Keputusan Pemilihan Perguruan Tingi Swasta

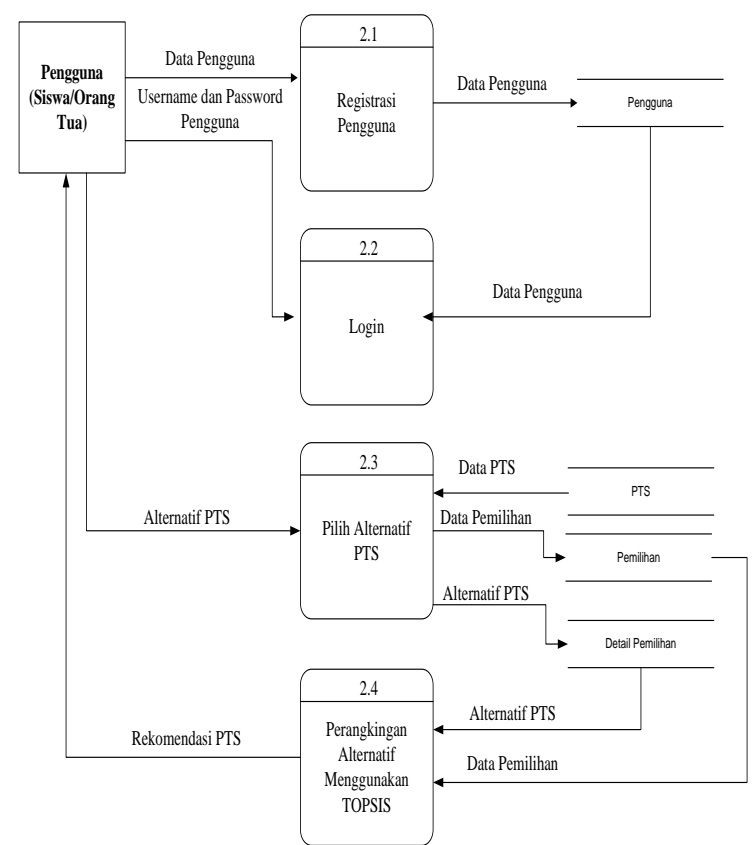

Sumber : (Mardiana \& Tanjung, 2017)

Gambar 5. Desain Diagram Detail 2.0 Sistem

Pendukung Keputusan Pemilihan Perguruan Tingi Swasta

Basis data yang digunakan dalam membangun Sistem Pendukung Keputusan Pemilihan Perguruan Tinggi Swasta terdiri dari 4 tabel, yaitu : administrator, pengguna, perguruan tinggi swasta, pemilihan, dan detail pemilihan. Relasi antar tabel ditunjukkan pada gambar 6.

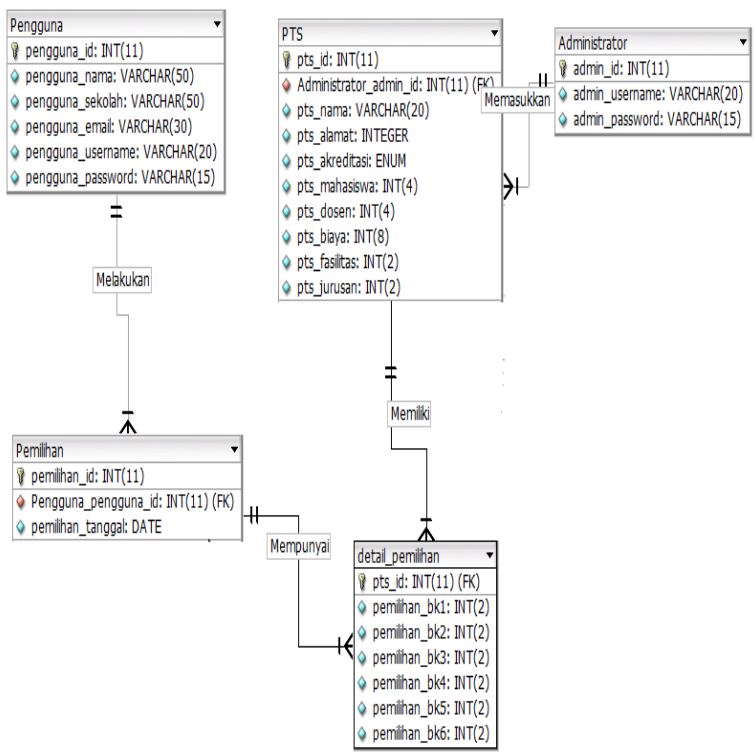

Sumber : (Mardiana \& Tanjung, 2017)

Gambar 6. Desain Basis Data Konseptual Sistem Pendukung Keputusan Pemilihan Perguruan Tingi Swasta 


\section{Implementasi Sistem}

Sistem pendukung keputusan merupakan solusi yang tepat dalam proses pengambilan keputusan pemilihan perguruan tinggi swasta sesuai dengan keinginan dan kemampuan siswa dan orang tua. Dalam sistem pendukung keputusan ini terdapat dua hak akses yaitu administrator dan pengguna (siswa atau orang tua). Halaman yang terdapat pada sistem pendukung keputusan pemilihan perguruan tinggi swasta berbasis web, sebagai berikut :

1. Halaman Administrator

Seorang administrator memiliki tugas dan tanggung jawab dalam mengelola sistem pendukung keputusan ini agar dapat diakses oleh pengguna (siswa atau orang tua). Administrator melakukan login untuk dapat masuk ke dalam sistem pendukung keputusan ini. Setelah melakukan login administrator dapat mengelola data perguruan tinggi swasta, data pengguna dan hak akses administrator.

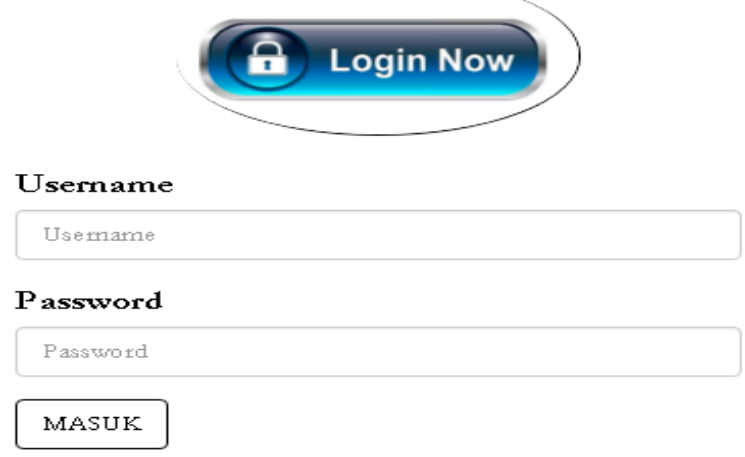

Sumber : (Mardiana \& Tanjung, 2017)

Gambar 7. Halaman Login Administrator Administitator Panel

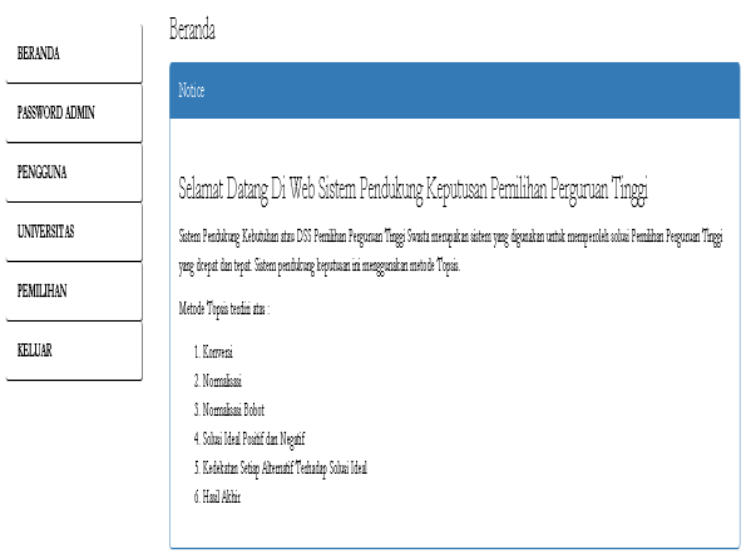

Sumber : (Mardiana \& Tanjung, 2017)

Gambar 8. Halaman Menu Administrator

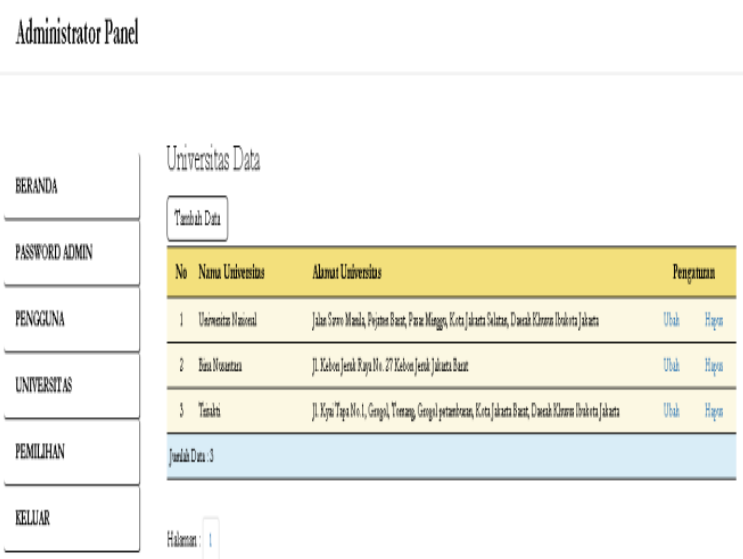

Sumber : (Mardiana \& Tanjung, 2017)

Gambar 9. Halaman Mengelola Data perguruan tinggi swasta

Administrator Panel

\begin{tabular}{|c|c|c|c|c|}
\hline \multirow{3}{*}{ 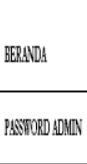 } & \multicolumn{4}{|l|}{ Pengowna Data } \\
\hline & 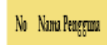 & tallesboh & Venure & Prgyinan \\
\hline & 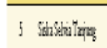 & 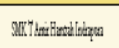 & sik & $\mathrm{A} p \bar{z}$ \\
\hline revoand & 6 Eitith & 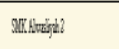 & in & $4 y_{n}$ \\
\hline 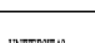 & 1 insilus & sunvilita & $\mathrm{sid}$ & 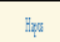 \\
\hline W Mitians & |withtats & & & \\
\hline FEMUHN & & & & \\
\hline Feld:R & 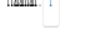 & & & \\
\hline
\end{tabular}

Sumber : (Mardiana \& Tanjung, 2017)

Gambar 10. Halaman Mengelola Data Pengguna

Administrator Panel

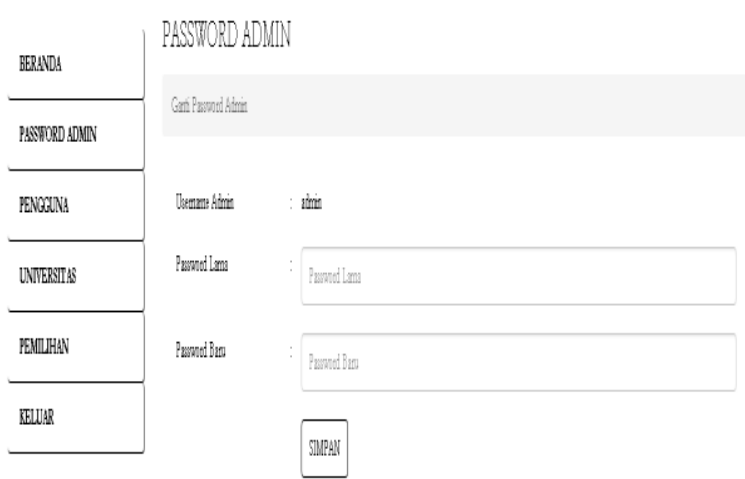

Sumber : (Mardiana \& Tanjung, 2017)

Gambar 11. Halaman Mengelola Data Administrator 
2. Implementasi Halaman Pengguna

Siswa dan orang tua dapat mengakses sistem pendukung keputusan ini dengan melakukan login menggunakan username dan password yang sudah teregistrasi. Pengguna memilih beberapa perguruan tinggi swasta untuk proses perangkingan berdasarkan kriteria dan bobot yang telah ditentukan. Sistem pendukung keputusan akan memberikan rekomendasi perguruan tinggi swasta yang sesuai keinginan dan kemampuan siswa dan orang tua.

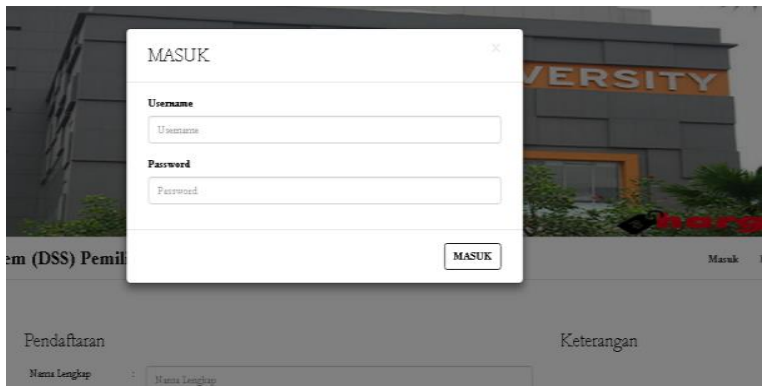

Sumber : (Mardiana \& Tanjung, 2017)

Gambar 12. Halaman Login Pengguna

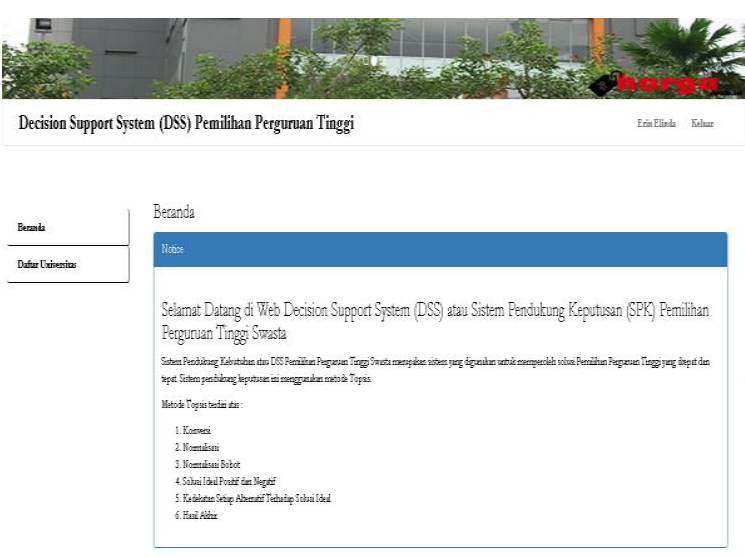

Sumber : (Mardiana \& Tanjung, 2017)

Gambar 13. Halaman Menu Pengguna

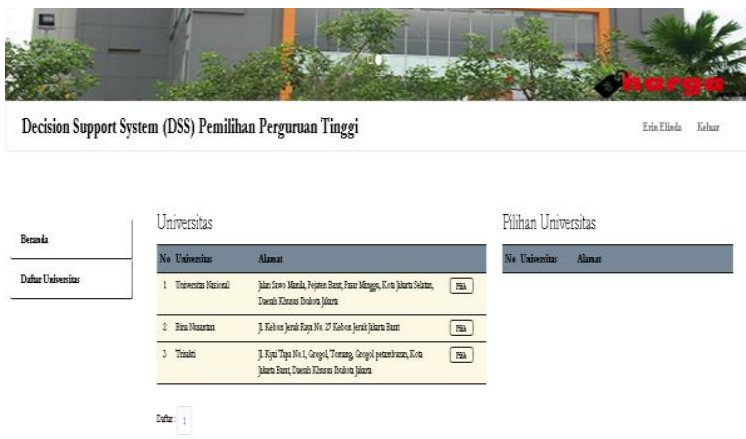

Sumber : (Mardiana \& Tanjung, 2017)

Gambar 14. Halaman Alternatif perguruan tinggi swasta

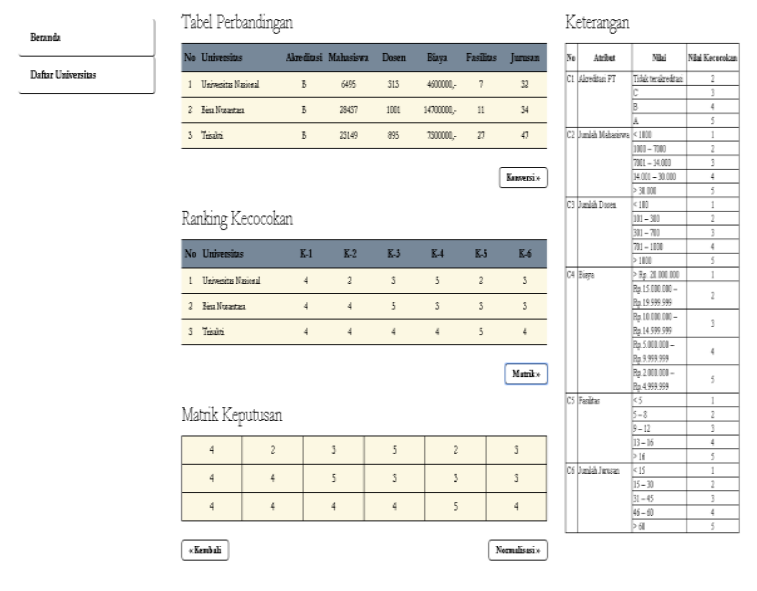

Sumber : (Mardiana \& Tanjung, 2017)

Gambar 15. Halaman Proses Matriks Kriteria Alternatif

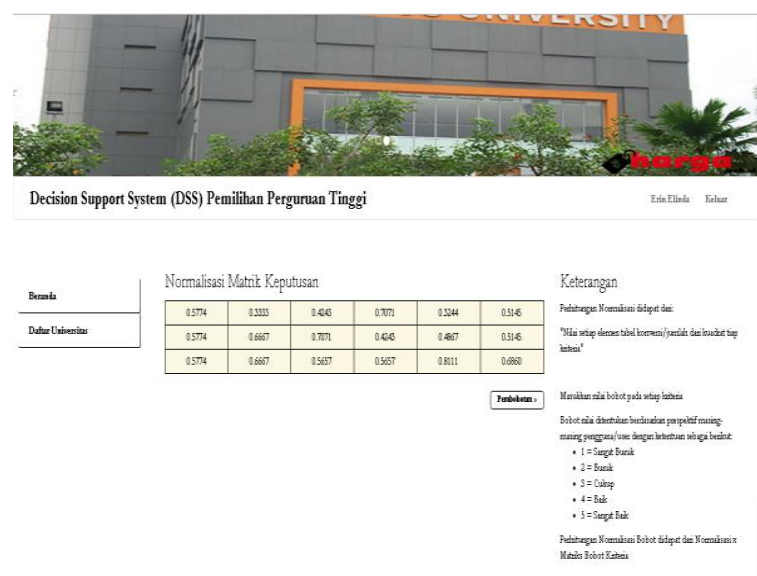

Sumber : (Mardiana \& Tanjung, 2017)

Gambar 16. Halaman Proses Matriks Keputusan Ternormalisasi

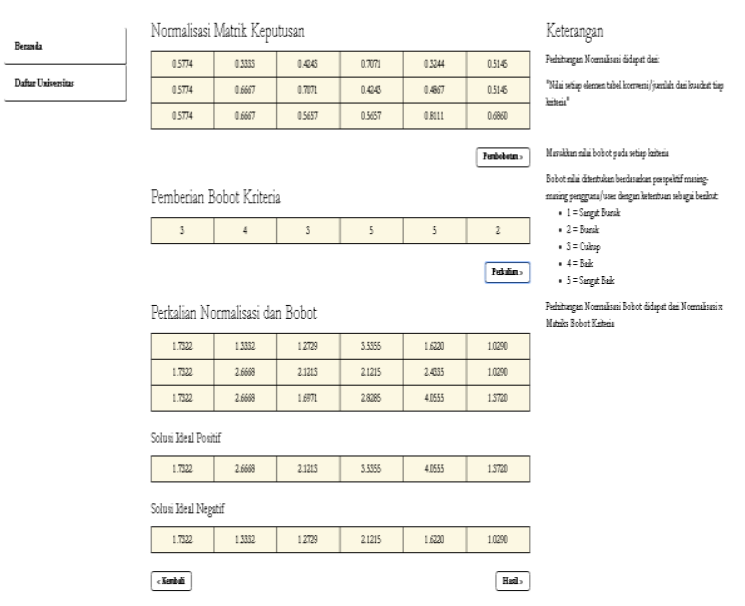

Sumber : (Mardiana \& Tanjung, 2017)

Gambar 17. Halaman Proses Matriks W* R 


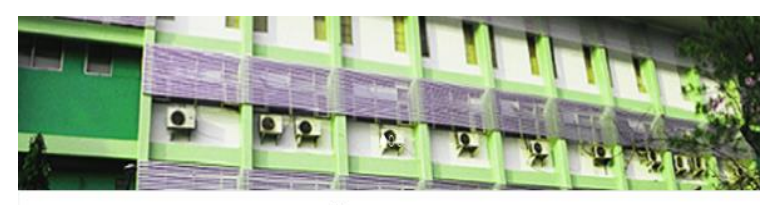

Decision Support System (DSS) Pemilihan Perguruan Tingei Fin flinh Fintur
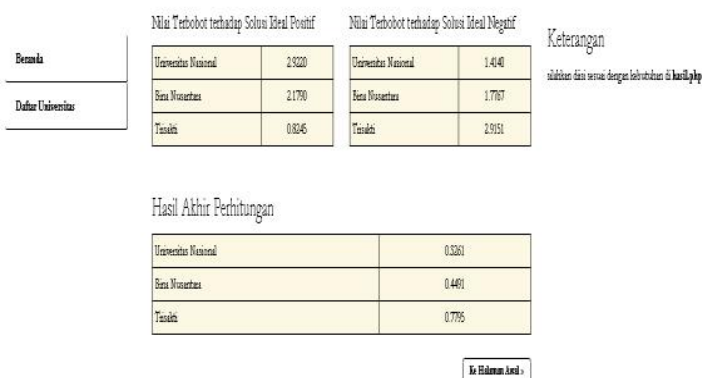

Sumber : (Mardiana \& Tanjung, 2017)

Gambar 18. Halaman Rekomendasi perguruan tinggi swasta

\section{Pengujian Sistem}

Pengujian terhadap sistem pendukung keputusan pemilihan perguruan tinggi swasta dilakukan dua tahap pengujian, sebagai berikut :

1. Pengujian Fungsional Sistem

Pengujian fungsional sistem dilakukan untuk mengetahui apakah sistem sudah memenuhi persyaratan yang ditentukan pengguna. Pengujian ini menggunakan metode pengujian black box dengan cara menjalankan sistem sesuai dengan skenario pengujian yang telah disusun, Hasil pengujian menunjukkan fitur-fitur pada sistem pendukung keputusan pemilihan perguruan tinggi swasta berfungsi dengan baik.

2. Pengujian Akurasi

Pengujian akurasi dilakukan untuk mengetahui tingkat akurasi hasil keluaran dari sistem pendukung keputusan. Untuk pengujian akurasi, hasil perangkingan sistem pendukung pemilihan perguruan tinggi swasta dibandingkan dengan dengan pilihan siswa dan orang tua terhadap alternatif perguruan tinggi swasta. Pengujian ini menggunakan sampel sebanyak 30 orang siswa untuk menentukan sebanyak tiga alternatif perguruan tinggi swasta kemudian memilih perguruan tinggi swasta yang sesuai keinginan dan kemampuan dari ketiga perguruan tinggi swasta tersebut. Selanjutnya, siswa diminta untuk menggunakan sistem pendukung keputusan dalam memilih perguruan tinggi swasta. Hasil pengujian diperoleh 25 orang memiliki pilihan yang sama dengan hasil sistem pendukung keputusan pemilihan perguruan tinggi swasta. Dari 25 pilihan yang benar tersebut maka akan diperoleh tingkat akurasi sistem pendukung keputusan pemilihan perguruan tinggi swasta, sebagai berikut :

$$
\text { Akurasi }=\frac{25}{30} \times 100 \%=83.33 \%
$$

Berdasarkan hasil perhitungan diperoleh akurasi sistem pendukung keputusan pemilihan perguruan tinggi swasta sebesar 83.33\%. Hasil pengujian akurasi tersebut menunjukkan TOPSIS dapat diterapkan pada sistem pendukung keputusan pemilihan perguruan tinggi swasta yang sesuai keinginan dan kemampuan siswa dan orang tua.

\section{SIMPULAN DAN SARAN}

Sistem pendukung keputusan pemilihan perguruan tinggi swasta menggunakan TOPSIS diimplementasikan berdasarkan enam kriteria perguruan tinggi swasta. Hasil pengujian menunjukkan fitur-fitur pada sistem pendukung keputusan pemilihan perguruan tinggi swasta sudah berfungsi dengan baik dan kinerja sistem mencapai akurasi sebesar 83,33\%. Dengan adanya sistem pendukung keputusan pemilihan perguruan tinggi swasta ini membantu siswa dan orang tua dalam memilih perguruan tinggi swasta yang sesuai keinginan dan kemampuan. Dalam pengembangan selanjutnya dapat dilakukan penambahan kriteria dan mengkombinasikan metode Analytical Hierarchy Process (AHP) dengan TOPSIS dalam pengambilan keputusan pemilihan perguruan tinggi swasta.

\section{DAFTAR REFERENSI}

Badan Pusat Statistik. (2018). Buku Statistik Indonesia 2018. Badan Pusat Statistik Indonesia.

Budilaksono, S., Suwarno, \& Herwanto, A. (2016). Sistem Pendukung Keputusan Pemilihan Perguruan Tinggi Swasta Program Teknik Informatika di Propinsi DKI Jakarta Dengan Metode AHP dan Promethee. In Seminar Nasional Teknologi Informasi dan Multimedia 2016 STMIK AMIKOM Yogyakarta (Vol. 2, pp. 58-70).

Danang, \& Nisar, M. F. (2017). Sistem Pendukung Keputusan Pemilihan PTS Jurusan Komputer Menggunakan Metode AHP di Kota Semarang. Simetris, 8(1), 45-52. 
Kementerian Pendidikan dan Kebudayaan, P. (2017). Ikhtisar Data Pendidikan dan Kebudayaan Tahun 2017/2018. Retrieved from

http://publikasi.data.kemdikbud.go.id/uploa dDir/isi_4B619F17-97F5-4B93-BB0B7F83B5512B0B_pdf

Kemeristekdikti, P. (2017). Buku Statistik Pendidikan Tinggi 2017.

Mardiana, T. (2018). Sistem Pendukung Keputusan Pemilihan Mobil Murah Ramah Lingkungan Menggunakan Metode TOPSIS. Jurnal TECHNO Nusa Mandiri, 15(1 Maret), 37-42.

Mardiana, T., Tanjung, S. (2017). Laporan Penelitian Sistem Pendukung Pemilihan Perguruan Tinggi Swasta Menggunakan
TOPSIS. Universitas Bina Sarana Informatika.

Surya, C. (2017). Sistem Pendukung Keputusan Pemilihan Perguruan Tinggi Menggunakan Fuzzy Multi Attribute Decision Making ( FMADM ) dan Simple Additive Weighting ( SAW ). Jaringan Sistem Informasi Robotik, 1(01, Maret), 18-24.

Triono, A., \& Aminudin, N. (2017). Sistem Pendukung Keputusan Pemilihan Perguruan Tinggi Dengan Simple Additive Weighting ( SAW). Konferensi Mahasiswa Sistem Informasi, 5(.1), 51-57.

Walidain, B., \& Ardian, Y. (2017). Sistem Pendukung Keputusan Pemilihan Perguruan Tinggi dan Jurusan Berbasis Web Menggunakan Metode TOPSIS. Jurnal Bimasakti, 1(5), 1-8. 